\title{
Culture of HEK293-EBNA1 Cells for Production of Recombinant Proteins
}

\author{
Roseanne Tom, Louis Bisson, and Yves Durocher
}

This protocol was adapted from "Transient Expression in HEK293-EBNA1 Cells," Chapter 12, in Expression Systems (eds. Dyson and Durocher). Scion Publishing Ltd., Oxfordshire, UK, 2007.

\section{INTRODUCTION}

Fast and efficient production of recombinant proteins (r-proteins) remains a major challenge for the academic and biopharmaceutical communities. Pure r-proteins are often required in large amounts (hundreds of milligrams to gram quantities) when being developed as biotherapeutics, or in smaller quantities (milligrams) for high-throughput screening campaigns and structural or functional studies. Mammalian cells are often preferred over prokaryotic systems when expressing cDNAs of mammalian origin due to their superior capability to conduct elaborate post-translational modifications. Largescale transfection of mammalian cells is now establishing itself as a "must-have" technology in the scientific community, as it allows the production of milligram to gram quantities of r-proteins within a few days after cDNA cloning into the appropriate expression vector. The HEK293 cell line stably expressing the Epstein-Barr virus nuclear antigen-1 (HEK293-EBNA1, or 293E) is the most commonly used cell line for large-scale transfection. When using expression vectors bearing the Epstein-Barr virus origin of replication, oriP (such as the pTT vector), a threefold improvement in r-protein yield is generally obtained over a similar non-oriP vector. This protocol describes a method for culturing HEK293EBNA1 cells which will then be used to produce recombinant proteins.

\section{RELATED INFORMATION}

A number of protocols are available for large-scale transfection of mammalian cells for production of milligram to gram quantities of r-proteins (e.g., Jordan et al. 1998; Schlaeger and Christensen 1999; Durocher et al. 2002; Baldi et al. 2005). Additional protocols can be found in this issue, including Transfection of HEK293-EBNA1 Cells in Suspension with Linear PEI for Production of Recombinant Proteins, Transfection of Adherent HEK293-EBNA1 Cells in a Six-Well Plate with Branched PEI for Production of Recombinant Proteins, and Transfection of HEK293-EBNA1 Cells in Suspension with 293fectin for Production of Recombinant Proteins. For a method to purify His-tagged transfected proteins, see Purification of His-Tagged Proteins Using Fractogel-Cobalt (this issue).

\section{MATERIALS}

CAUTIONS AND RECIPES: Please see Appendices for appropriate handling of materials marked with $<!>$, and recipes for reagents marked with $<\mathrm{R}>$. 


\section{Reagents}

All reagents added to cultures and media must be sterile.

Calf serum, cosmic (HyClone)

Thaw the frozen serum thoroughly at $37^{\circ} \mathrm{C}$. Heat-inactivate for $30 \mathrm{~min}$ in $a 56^{\circ} \mathrm{C}$ bath, swirling the bottle occasionally for thorough heat distribution. Store aliquots at $-20^{\circ} \mathrm{C}$.

Cell lines, 293E or 293-6E (NRC-BRI)

Other HEK293 cell lines (e.g., 293T, 293S, and 293F) can also be used, but with somewhat lower r-protein yields. Use appropriate culture medium listed below, depending on cells used.

Culture medium, prewarmed, for 293E cells (e.g., LC-SFM medium [custom low-calcium HSFM formulation; Invitrogen])

Supplement with $1 \%(\mathrm{v} / \mathrm{v})$ serum and $0.1 \%(\mathrm{w} / \mathrm{v})$ Pluronic F-68 prior to use.

Culture medium, prewarmed, for 293-6E cells (e.g., F17 culture medium [Invitrogen] or HyQ SFM4Transfx-293 [HyClone])

Add $10 \mathrm{~mL}$ of Pluronic F-68 stock solution per liter of culture medium to a final concentration of $0.1 \%(\mathrm{w} / \mathrm{v})$ prior to use.

$<$ !>DMSO, cell culture grade (Sigma)

$<$ !>G418, $50 \mathrm{mg} / \mathrm{mL}$ stock solution (Invitrogen)

$<$ R $>$ PBS containing $25 \mathrm{mg} / \mathrm{mL}$ Erythrosin B (Sigma)

Pluronic F-68, 10\% stock solution (w/v) (Invitrogen)

\section{Equipment}

Rinse glassware three times using Milli-Q $\mathrm{H}_{2} \mathrm{O}$ (or equivalent), followed by steam sterilization.

Boxes, Styrofoam (large and 20-position small) or programmable cooler (see Steps 12 and 16)

Centrifuge

Cryovials

Flasks, Erlenmeyer, glass, reusable (Corning)

Flasks, Erlenmeyer, plastic, $125-\mathrm{mL}$ disposable shake (Corning)

Freezer at $-80^{\circ} \mathrm{C}$

$<$ !>Freezer storage, liquid nitrogen, vapor phase

Hemocytometer

Hood, laminar flow

Incubator preset to $37^{\circ} \mathrm{C}$, humidified, $5 \% \mathrm{CO}_{2}$

Microscope

Shaker, orbital

Ensure that the orbital shaker can operate continuously under humidified conditions. Do not shut off the orbital shaker in the humidified incubator or it will seize upon subsequent use. When not in use for cultures, leave the shaker agitating or remove it from the incubator until needed. Avoid shakers with digital controls, as they are susceptible to humidity. The shaker must contain holders for shake flask sizes ranging from 50 to $2000 \mathrm{~mL}$. If no holders are supplied, equip the platform with an anti-slip adhesive mat. Shake flasks must stay on the platform up to $120 \mathrm{rpm}$.

Tubes, conical, $15-\mathrm{mL}$

Water bath preset to $37^{\circ} \mathrm{C}$

\section{METHOD}

Conduct all operations aseptically in a laminar flow hood. Cells growing in serum-free media are highly sensitive to chemical contamination; thorough rinsing of all equipment that contacts the cells with highly pure water is compulsory.

\section{Cell Thawing and Maintenance}

1. Prepare a $15-\mathrm{mL}$ conical tube containing $10 \mathrm{~mL}$ of prewarmed cell culture medium appropriate for the cell line to be used. 
2. Thaw the cells rapidly in a $37^{\circ} \mathrm{C}$ water bath.

3. Add the cells to the $15-\mathrm{mL}$ tube. Invert to mix.

4. Dilute a $100-\mu \mathrm{L}$ aliquot of cells with $100 \mu \mathrm{L}$ of PBS containing $25 \mathrm{mg} / \mathrm{mL}$ erythrosin B. Determine the cell density and viability using a hemocytometer.

5. Centrifuge the cells at $200 \mathrm{~g}$ for $5 \mathrm{~min}$ at room temperature.

6. Decant the supernatant. Loosen the pellet by gently tapping the tube. Dilute the cells to $2.5 \times 10^{5}$ cells/mL in a $125-\mathrm{mL}$ disposable shake flask using cell culture medium.

Operating culture volumes must be in the range of $16 \%-33 \%$ of the nominal shake flask volume for sufficient oxygenation.

7. Place the shake flask on the orbital shaker $(\sim 120 \mathrm{rpm})$ in the incubator. Center the shaker in the incubator. Make sure that the walls, door, and wire are not contacted during agitation.

8. Count the cells at $48 \mathrm{~h}$ post-thawing. If necessary, dilute to $2.5 \times 10^{5}$ cells $/ \mathrm{mL}$ using cell culture medium.

9. When the doubling time is $24 \mathrm{~h}$ for two consecutive passages, subculture every 2 or $3 \mathrm{~d}$ to maintain cell densities between $2.5 \times 10^{5}$ and $1.2 \times 10^{6}$ cells $/ \mathrm{mL}$ using medium supplemented with G418 $(25 \mu \mathrm{g} / \mathrm{mL}$ or $50 \mu \mathrm{g} / \mathrm{mL}$, for $293-6 \mathrm{E}$ or $293 \mathrm{E}$ cells, respectively).

See Troubleshooting.

10. Dilute the cultures to $1.5 \times 10^{5}$ or $7.5 \times 10^{4}$ cells $/ \mathrm{mL}$ for weekends or long weekends ( 3 or $4 \mathrm{~d}$, respectively).

\section{Cell Freezing}

11. Prepare the freezing mixture by adding DMSO to fresh cell culture medium $(10: 90, v / v)$.

12. Label the cryovials. Place in a small Styrofoam box. Prechill the large Styrofoam box in a $-80^{\circ} \mathrm{C}$ freezer.

13. Count the cells. Determine the volume needed for cryopreservation. Cells must be in the exponential phase (between $8 \times 10^{5}$ and $1.2 \times 10^{6}$ cells $/ \mathrm{mL}$ ).

14. Centrifuge the cells at $200 \mathrm{~g}$ for $5 \mathrm{~min}$. Decant the supernatant. Dissociate the pellet by gently tapping the tube.

15. Add the freezing medium drop-wise to the cells while swirling the tube to obtain the desired density (i.e., $5 \times 10^{6}$ to $5 \times 10^{7}$ cells $/ \mathrm{mL}$ per vial).

16. Quickly aliquot the cells into the labeled vials. Immediately transfer to $\mathrm{a}-80^{\circ} \mathrm{C}$ freezer. Do not open the freezer door for at least $2 \mathrm{~h}$.

Alternatively, freeze cells at $1^{\circ} \mathrm{C} / \mathrm{min}$ in a programmable cooler.

17. Transfer the vials to liquid nitrogen freezer storage (vapor phase) the following day. Store for a maximum of $4 d$.

\section{TROUBLESHOOTING}

Problem: The cells do not grow well.

[Step 9]

Solution: If cells do not grow with the expected doubling time, consider the following:

1. The cultureware is not sufficiently clean. Glassware for all culture manipulations and reagent preparations must be rinsed at least three times with high-purity $\mathrm{H}_{2} \mathrm{O}$.

2. The $\mathrm{H}_{2} \mathrm{O}$ used may not be sufficiently pure. Check the source of the ultrapure $\mathrm{H}_{2} \mathrm{O}$.

3. Check that the filtration system (if applicable) used to make the ultrapure $\mathrm{H}_{2} \mathrm{O}$ is functioning properly. 
4. Cell aggregation can give a false impression of slower growth rates. Check regularly that the orbital shaker is at the right speed and that the incubator is at the correct temperature and is supplying the prescribed amount of $\mathrm{CO}_{2}$.

5. The cells may be too old. The number of cell passages indicates the age of the cells in service. A new cryovial can be thawed every 3 mo, on average.

6. Verify expiration dates, culture medium lots, and batches of additives used (e.g., Pluronic F-68 and antibiotics).

7. Check for mycoplasma contamination; if positive, thaw new cells.

\section{REFERENCES}

Baldi, L., Muller, N., Picasso, S., Jacquet, R., Girard, P., Thanh, H.P., Derow, E., and Wurm, F.M. 2005. Transient gene expression in suspension HEK-293 cells: Application to large-scale protein production. Biotechnol. Prog. 21: 148-153.

Durocher, Y., Perret, S., and Kamen, A. 2002. High-level and high-throughput recombinant protein production by transient transfection of suspension-growing human 293-EBNA1 cells. Nucleic Acids Res. 30: E9. doi: 10.1093/nar/30.2.e9.
Jordan, M., Köhne, C., and Wurm, F.M. 1998. Calcium-phosphate mediated DNA transfer into HEK-293 cells in suspension: Control of physicochemical parameters allows transfection in stirred media. Transfection and protein expression in mammalian cells. Cytotechnology 26: 39-47.

Schlaeger, E.-J. and Christensen, K. 1999. Transient gene expression in mammalian cells grown in serum-free suspension culture. Cytotechnology 30: 71-83. 


\section{Culture of HEK293-EBNA1 Cells for Production of Recombinant Proteins}

Roseanne Tom, Louis Bisson and Yves Durocher

Cold Spring Harb Protoc; doi: 10.1101/pdb.prot4976

\begin{tabular}{|c|c|}
\hline $\begin{array}{r}\text { Email Alerting } \\
\text { Service }\end{array}$ & Receive free email alerts when new articles cite this article - click here. \\
\hline $\begin{array}{l}\text { Subject } \\
\text { Categories }\end{array}$ & $\begin{array}{l}\text { Browse articles on similar topics from Cold Spring Harbor Protocols. } \\
\text { Analysis of Protein Expression in Cultured Cells (57 articles) } \\
\text { Cell Biology, general (1382 articles) } \\
\text { Cell Culture (301 articles) } \\
\text { Expression of Cloned Genes ( } 80 \text { articles) } \\
\text { High-Throughput Analysis, general (155 articles) } \\
\text { Protein Expression and Interactions (93 articles) } \\
\text { Proteins and Proteomics, general (575 articles) } \\
\text { Proteome Analysis (56 articles) }\end{array}$ \\
\hline
\end{tabular}

